Web Jurnal:

http://ejournal.kemenperin.go.id/jli

\title{
Stabilitas madu herbal dengan penambahan emulsifier dan antioksidan menggunakan metode spontan
}

\section{Stability of herbal honey with emulsifier and antioxidant using spontaneous emulsification method}

\author{
Nur Ahmad Habibi, Nurheni Sri Palupi, dan Azis Boing Sitanggang \\ Institut Pertanian Bogor \\ Jl. Raya Dramaga, Kabupaten Bogor, Indonesia \\ Email : nurahmadhabibi95@gmail.com
}

\begin{tabular}{l}
\hline INFO ARTIKEL \\
\hline Sejarah artikel: \\
Diterima: \\
10 April 2020 \\
Direvisi: \\
28 November 2020 \\
Diterbitkan: \\
28 Desember 2020
\end{tabular}

Kata kunci:

madu herbal; stabilitas; tween 80; tokoferol

\begin{abstract}
ABSTRAK
Madu herbal yang mengandung minyak jintan hitam dan minyak zaitun rentan mengalami perubahan stabilitas selama masa penyimpanan,yang meliputi terjadinya separasi (pemisahan) maupun oksidasi. Penelitian bertujuan mengetahui pengaruh pemberian emulsifier dan antioksidan terhadap stabilitas madu herbal. Penelitian menggunakan rancangan acak lengkap faktorial dengan dua kali pengulangan. Faktor pertama adalah konsentrasi antioksidan tokoferol $(0 ; 0,005 ; 0,01 \%)$ dan faktor kedua adalah konsentrasi emulsifier Tween $80(0 ; 0,001 ; 0,002 \%)$ sehingga terdapat 9 kombinasi yang dihasilkan. Madu herbal dibuat dengan menggunakan metode spontan. Penelitian mengamati distribusi ukuran partikel, stabilitas terhadap pemisahan, dan Accelerated Shelf Life Test (ASLT) untuk memprediksi umur simpan. Berdasarkan pengamatan, diketahui bahwa distribusi ukuran partikel terbesar adalah pada madu herbal kelompok T1TW1 (tokoferol 0 ppm dan Tween 80 0\%) dengan ukuran 1004,70 $\pm 5,80$ nm. Distribusi partikel terkecil adalah pada madu herbal kelompok T3TW3 (tokoferol

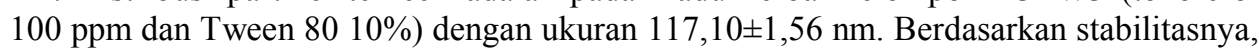
perlakuan kelompok 9 (T3Tw3) mampu menahan laju pemisahan emulsi yang terjadi dibandingkan kelompok lainnya. Berdasarkan pengujian ASLT madu dengan penambahan antioksidan dan emulsifier memiliki umur simpan 241 hari, dan yang tidak ditambahkan 140 hari. Kesimpulan dari penelitian ini adalah penambahan antioksidan tokoferol dan emulsifier Tween 80 dapat meningkatkan stabilitas madu herbal secara bermakna.
\end{abstract}

Keywords: herbal honey; stability; tween 80; tocopherol.

\begin{abstract}
Herbal honey with blackseed oil and olive oil is susceptible to change in stability during the storage period, such as separation and oxidation. The aim of this study was to observe the effect of emulsifier and antioxidant to stability of herbal honey. This study used a completely randomized factorial design with two repetitions. The first factor was concentration antioxidant tocopherol $(0 ; 0,005 ; 0,01 \%)$ and the second factor was concentration of emulsifier Tween 80 (0;0,001; 0,002\%) so there were 9 combinations. Herbal honey was made using the spontaneous method. The study observed particle size distribution, stability against separation, and predict shelf life. Based on observation, the largest particle size distribution was in the herbal honey T1TW1 group with size 1004.70 $\pm 5.80 \mathrm{~nm}$. The smallest particle distribution was in the T3TW3 group with size $117.10 \pm$ $1.56 \mathrm{~nm}$. Based on the stability, T3TW3 group was able to keep the rate of emulsion separation that occurs compared to other groups. Based on ASLT test, herbal honey with antioxidan and emulsifier had shelf life 241 days and without 140 days. Conclusion this study is antioxidant tocopherol and Tween 80 emulsifier can improve the stability of herbal honey significant.
\end{abstract}




\section{Pendahuluan}

Saat ini telah banyak dikembangkan produk madu herbal yang dikombinasikan dengan bahan-bahan lain, seperti minyak jintan hitam (Nigella sativa oleum) dan minyak zaitun (Olea europaea) untuk menambah khasiat di dalamnya. Menurut penelitian (Shikh Maidin et al., 2018) madu yang dikombinasikan dengan minyak jintan hitam dapat memiliki efek yang lebih baik dibandingkan jika diberikan dalam bentuk bahan tunggal terutama dalam melindungi membran sel sperma dari kerusakan akibat stres oksidatif. Selain itu, pemberian madu yang dikombinasikan dengan minyak zaitun juga memiliki efek yang baik untuk melindungi dan meningkatkan kesehatan organ hati (Alturkistani et al., 2019).

Meskipun memiliki potensi yang baik untuk kesehatan, minyak jintan hitam dan minyak zaitun rentan terhadap reaksi oksidasi yang disebabkan oleh tingginya kandungan asam lemak tak jenuh ganda di dalamnya, terutama linoleat (Hassanien and Wahdan, 2011). Reaksi oksidasi merupakan faktor utama yang menyebabkan kerusakan serius pada kualitas minyak, terutama dalam kandungan gizi dan sifat sensorik selama penyimpan (Aladedunye and Przybylski, 2009; Vrbiková et al., 2014)

Selama masa penyimpanan, stabilitas madu herbal mengalami perubahan. Pada tahap awal, terjadi pemisahan emulsi antara fase minyak dari minyak jintan hitam dan minyak zaitun dengan fase air yang terkandung dalam madu. Hal ini disebabkan karena perbedaan densitas antara kedua bahan (Murakami et al., 2014). Kondisi ini mengakibatkan minyak yang memiliki densitas lebih rendah daripada madu mengalami perpindahan ke permukaan madu herbal. Perpindahan menghasilkan kemungkinan reaksi oksidasi karena paparan oksigen di ruang permukaan botol kemasan menjadi besar (Pristouri et al., 2010).

Madu herbal yang dikombinasikan dengan minyak jintan hitam dan minyak zaitun memiliki masalah utama diantaranya adalah pemisahan dan oksidasi minyak yang mengakibatkan madu menjadi berwarna cokelat gelap di permukaan dan lebih kental sehingga sulit untuk dituangkan. Selain itu, terdapat perubahan rasa dan aroma setelah disimpan dalam hitungan bulan saat seharusnya madu memiliki umur simpan 20-36 bulan (Fallico et al., 2009; Srivastava and Semwal, 2013).

Ketidakstabilan madu herbal diawali dengan terjadinya pemisahan campuran yang disebabkan karena tidak terbentuknya emulsi yang baik di dalamnya. Kondisi ini dapat diperbaiki dengan menggunakan emulsifier. Pada produk madu herbal, jenis emulsi yang dihasilkan adalah jenis emulsi minyak-dalam-air $(\mathrm{o} / \mathrm{w})$, dengan fase terdispersi adalah minyak jintan hitam dan minyak zaitun, serta fase pendispersinya adalah madu. Diketahui bahwa persyaratan untuk membuat emulsi o/w adalah emulsifier yang digunakan harus memiliki nilai Hydrophilic Lipophilic Balance (HLB) 8-18 (Komaiko and Mcclements, 2016).

Tween 80 atau polysorbate 80 merupakan jenis emulsifier yang dapat digunakan untuk meningkatkan stabilitas madu herbal. Hal ini dikarenakan emulsifier jenis ini memiliki nilai HLB 15 (Hassan, 2015). Selain itu, Tween 80 relatif stabil dalam kondisi asam sehingga sangat cocok apabila digunakan untuk membuat emulsi $\mathrm{o} / \mathrm{w}$ dalam madu yang memiliki $\mathrm{pH}$ asam (Banfalvi, 2016).

Selain terjadinya pemisahan, madu herbal juga rentan mengalami oksidasi yang dapat mengakibatkan kerusakan pada kualitas mutunya, kondisi ini dapat diperbaiki dengan penambahan antioksidan untuk mencegah terjadinya oksidasi. Tokoferol merupakan salah satu jenis antioksidan yang dapat digunakan untuk meningkatkan stabilitas madu herbal (Choe and Min, 2009).

Tokoferol merupakan antioksidan yang biasa ditemukan dalam minyak. Antioksidan jenis ini biasanya digunakan sebagai bahan tambahan untuk meningkatkan stabilitas emulsi minyak (Choe and Min, 2009). Di sisi lain, tokoferol memiliki kemampuan untuk membantu pembentukan emulsi yang optimal dan mencegah bergabungnya alkil radikal di dalam minyak yang dapat menyebabkan kerusakan pada emulsi yang dihasilkan (Kim et al., 2018).

Pada industri kecil, pembuatan emulsi umumnya dilakukan dengan teknologi sederhana, yaitu dengan menggunakan pendekatan energi rendah. Salah satu metode yang dapat diaplikasikan adalah dengan metode secara spontan.

Secara praktis, metode pembuatan emulsi secara spontan biasanya dilakukan dengan meneteskan fase terdispersi (minyak dan emulsifier) ke dalam wadah yang mengandung fase pendispersi (air). Tetesan minyak halus $(<100 \mathrm{~nm})$ dapat terbentuk jika komposisi (emulsifier dan minyak) dan kondisi persiapan (suhu, laju pengadukan, dan kecepatan penetesan) dioptimalkan. Pengadukan ringan dapat memfasilitasi pemecahan mikroemulsi minyak dan menggerakkan molekul emulsifier, minyak, dan air (Komaiko and McClements, 2015).

Oleh karena itu, penelitian ini bertujuan mengevaluasi pengaruh penggunaan emulsifier Tween 80 dan antioksidan tokoferol dalam meningkatkan stabilitas madu herbal yang ditambahkan dengan minyak jintan hitam dan minyak zaitun umur simpan melalui metode spontan terhadap pemisahan (separasi) dan terjadinya kerusakan akibat reaksi oksidasi melalui Accelerated Shelf Life Test (ASLT) selama masa penyimpanan.

\section{Metode}

Penelitian dilakukan pada bulan SeptemberNovember 2019 di laboratorium kimia pangan departemen ilmu dan teknologi pangan, fakultas teknik pertanian IPB, laboratorium nanoteknologi Indonesia dan laboratorium PT XYZ.

Bahan-bahan yang digunakan adalah minyak jintan hitam merek Yahia Sayed Omar dari Ethiopia, minyak zaitun dari lantabura, madu murni dari CV Honeysia Alamindo Barokah, tokoferol dari sumber berlian kimia, Tween 80 dari sumber berlian kimia, air dan botol PET.

Peralatan yang digunakan meliputi refraktometer, $\mathrm{pH}$ meter, Particle size analyze diffraction laser (LS-PSA) (Beckman Coulter, USA), buret, erlenmeyer, brookfield viscometer, skala digital gelas ukur, mixer, spektrofotometer, kamera HP dan inkubator. 


\subsection{Rancangan penelitian}

Penelitian ini menggunakan Rancangan Acak Lengkap (RAL) Faktorial dengan dua faktor dua kali pengulangan. Faktor pertama adalah konsentrasi antioksidan tokoferol dengan 3 taraf konsentras. Faktor kedua adalah konsentrasi pengemulsi tween 80 yang terdiri dari 3 taraf konsentrasi.

Perlakuan dari penelitian ini adalah hasil kombinasi antar faktor dari seluruh taraf perlakuan. Dengan demikian, dalam penelitian ini terdapat $3 \times 3$ kombinasi atau 9 kombinasi. Faktor I adalah konsentrasi antioksidan tokoferol yang terdiri dari 3 perlakuan yaitu T1 $(0 \%)$, T2 $(0,005 \%)$ dan T3 $(0,01 \%)$. Faktor II adalah konsentrasi pengemulsi tween 80 yang terdiri dari 3 perlakuan yaitu Tw1 (0 \%), Tw2 $(0,001 \%)$ dan Tw3 $(0,002 \%)$. Berikut hasil kombinasi dari kedua faktor tersebut:

Tabel 1

Kelompok perlakuan

\begin{tabular}{llll}
\hline \multirow{2}{*}{$\begin{array}{l}\text { Konsentrasi } \\
\text { tokoferol }\end{array}$} & \multicolumn{3}{l}{ Konsentrasi Tween 80 } \\
\cline { 2 - 4 } & B1 & B2 & B3 \\
\hline A1 & T1TW1 & T1TW2 & T1TW3 \\
\hline A2 & T2TW1 & T2TW2 & T2TW3 \\
\hline A3 & T3TW1 & T3TW2 & T3TW3 \\
\hline
\end{tabular}

Madu herbal dibuat dengan menggunakan metode spontan. Dalam setiap pembuatan madu herbal terdiri dari komposisi madu 97-98 \%, minyak jintan hitam $1 \%$, minyak zaitun $1 \%$, tokoferol $0-0,01 \%$ dan tween 800 $0,002 \%$ dengan total berat produk $2 \mathrm{~kg}$ per pembuatan. Adanya variasi dalam percobaan dimaksudkan untuk mendapatkan hasil kombinasi yang paling terbaik dalam menjaga kestabilan madu herbal.

\subsection{Prosedur pembuatan madu herbal}

Pembuatan madu herbal dimulai dengan mencampurkan minyak zaitun dan minyak jintan hitam dengan Tween 80 dan tokoferol menggunakan mixer kecepatan 600 rpm selama 10 menit. Kemudian dilakukan penetesan perlahan menggunakan buret ke dalam larutan madu yang telah dipanaskan pada suhu $50^{\circ} \mathrm{C}$. Proses penetesan dilakukan perlahan disertai dengan pengadukan madu pada kecepatan $60 \mathrm{rpm}$ hingga larutan minyak habis. Setelah proses penetesan selesai, dilakukan pasteurisasi madu herbal dengan suhu $65^{\circ} \mathrm{C}$ selama 10 menit. Pada tahap akhir, madu herbal dikemas menggunakan botol PET pada suhu $55-57^{\circ} \mathrm{C}$ (Ariviani et al., 2015).

\subsection{Pengujian viskositas}

Pengujian dilakukan dengan mengamati viskositas madu menggunakan viskometer brookfield. Pengujian diawali dengan memasukkan madu $100 \mathrm{ml}$ ke dalam gelas, kemudian masukkan spindle dari viscometer (Dianingsih et al., 2016). Nilai viskositas diperoleh melalui rumus sebagai berikut.
Nilai viskositas $=$ nilai pengukuran $\mathrm{x}$ faktor

\subsection{Pengukuran ukuran partikel emulsi}

Pengukuran ukuran partikel dilakukan menggunakan Particle Size Analyzer Laser Diffraction (LS-PSA) (Beckman Coulter, USA) dengan unit ukuran partikel dari instrumen yang digunakan adalah nanometer $(\mathrm{nm})$. Rentang pengukuran dari perangkat adalah 100 - 9000 nm. LS-PSA terhubung ke komputer yang dilengkapi dengan perangkat lunak LS Coulter 100 (Picandet, 2017).

Pengukuran diawali dengan melarutkan madu herbal ke dalam aquades. Selanjutnya, aquades dituangkan ke dalam lubang sampel hingga memenuhi seluruh lubang, kemudian sampel dimasukkan hingga mencapai kisaran pembacaan $8-12 \%$. Semua sampel dianalisis berdasarkan model Fraunhofer dalam perangkat lunak LS Coulter 100. Nilai yang akan diambil adalah nilai D10, D50 dan D90, serta rerata ukuran droplet emulsi.

\subsection{Pengujian Stabilitas terhadap separasi}

Stabilitas emulsi diuji dengan melihat kemampuan emulsi dalam menghambat separasi (pemisahan) selama penyimpanan. Pemisahan emulsi diamati dengan menempatkan produk madu dalam inkubator $40^{\circ} \mathrm{C}$ selama 1 minggu untuk mempercepat laju reaksi. Pemilihan suhu tersebut dikarenakan pada suhu tersebut proses pemisahan akan lebih cepat untuk diamati. Pengamatan dilakukan secara visual selama satu minggu (Arpah, 2007). Hasil visual pemisahan didokumentasikan menggunakan kamera Handphone Samsung J2.

\subsection{Pengujian stabilitas umur simpan dengan menggunakan metode accelerated shelf life test}

Pengujian stabilitas dilakukan dengan menggunakan pengujian stabilitas ASLT metode Arrhenius pada kelompok madu yang memiliki stabilitas separasi terbaik (A) dan pada kelompok yang tanpa ditambahkan antioksidan dan emulsifier (B). Sampel madu terpilih disimpan dalam inkubator suhu 35,40 dan $45^{\circ} \mathrm{C}$. Parameter yang digunakan dalam pengujian adalah nilai Thiobarbituric acid TBA. Nilai TBA maksimum pada produk yang menjadi acuan adalah $0,27 \mathrm{mg} / \mathrm{kg}$ sampel berdasarkan penelitian pendahuluan (Arpah, 2007).

Perhitungan umur simpan dengan model Arrhenius dilakukan dengan mencari nilai $\ln \mathrm{k}$ dari nilai $\mathrm{k}$ atau nilai konstanta penurunan mutu yang diperoleh dari kemiringan persamaan regresi grafik ordo yang sesuai untuk masing-masing suhu penyimpanan. Oleh karena produk yang diuji adalah produk yang rentan terhadap oksidasi lipid, maka ordo yang digunakan adalah ordo 0 . Selanjutnya, dibuat plot Arrhenius dengan sumbu $\mathrm{x}$ menyatakan nilai $1 / \mathrm{T}$ (K-1 ) dan sumbu y menyatakan nilai $\mathrm{ln} \mathrm{k}$ pada masing-masing suhu penyimpanan yang digunakan. Hasil regresi linier yang diperoleh pada kurva Arrhenius dapat digunakan untuk memprediksi umur simpan produk dengan menggunakan rumus sebagai berikut. 


$$
\mathrm{k}=\mathrm{k}_{\mathrm{o}} \exp ^{-\mathrm{Ea} / \mathrm{RT}}
$$

$\mathrm{k}=$ konstanta penurunan mutu

$\mathrm{R}=\operatorname{konstanta}$ gas $(1,987 \mathrm{kal} / \mathrm{mol} \mathrm{K})$

$\mathrm{T}=$ suhu mutlak $(\mathrm{K})$

$\mathrm{Ea}=$ energi aktivasi

$\mathrm{k}_{0} \quad=$ konstanta (tidak tergantung pada suhu)

Persamaan tersebut diubah menjadi:

$$
\ln \mathrm{k}=\ln \mathrm{k}_{\mathrm{o}}+\left(\frac{-\mathrm{Ea}}{R}\right)\left(\frac{1}{T}\right)
$$

$\mathrm{k}_{0}$ merupakan konstanta penurunan mutu produk yang tidak tergantung pada suhu, sedangkan $\mathrm{k}$ merupakan konstanta penurunan mutu dari salah satu kondisi suhu yang digunakan, dan $\mathrm{Ea} / \mathrm{R}$ merupakan gradien yang diperoleh dari plot Arrhenius. Hasil perhitungan menggunakan rumus ini akan diperoleh nilai $\mathrm{k}_{0}$.

Umur simpan diperoleh dengan rumus :

$$
\mathrm{t}=\frac{A o-A t}{k}(\text { Reaksi ordo } 0)
$$

$\mathrm{t}=$ prediksi umur simpan (hari)

Ao $=$ nilai mutu awal

At $=$ nilai mutu produk yang tersisa setelah waktu $\mathrm{t}$

$\mathrm{k}=$ konstanta reaksi pada suhu penyimpanan yang diinginkan

\subsubsection{Pengujian TBA}

Prosedur analisis dimulai dengan menimbang 10 gram sampel madu herbal ke dalam erlenmeyer $250 \mathrm{ml}$. Erlenmeyer berisi sampel ditambahkan 2,5 ml larutan $\mathrm{HCl} 4 \mathrm{~N}$, kemudian ditambahkan 97,5 ml aquades. Setelah itu, dilakukan proses destilasi untuk mendapatkan destilat sebanyak $50 \mathrm{ml}$. Filtrat yang dihasilkan diambil sebanyak $5 \mathrm{ml}$ dan ditambahkan dengan $5 \mathrm{ml}$ larutan TBA (dibuat dengan melarutkan $0,2883 \mathrm{~g}$ thiobarbituric acid dalam 90\% asam asetat glasial hingga mencapai volume $100 \mathrm{ml}$ ). Tabung reaksi ditutup, divortex, dan diletakkan dalam gelas piala berisi air yang dipanaskan pada suhu $100^{\circ} \mathrm{C}$ selama 35 menit (Husain et al., 2018).

Selanjutnya, sampel didinginkan dan diukur absorbansinya dengan spektrofotometer pada panjang gelombang $528 \mathrm{~nm}$, dan sebagai blanko adalah aquades yang mendapatkan perlakuan sama dengan sampel. Bilangan TBA dihitung dan dinyatakan dalam satuan $\mathrm{mg}$ per kg sampel (ppm). Bilangan TBA dihitung dengan persamaan sebagai berikut

$$
\text { Nilai TBA }=7,8 \times \text { absorbansi }
$$

\section{Hasil dan pembahasan}

\subsection{Viskositas emulsi madu herbal}

Madu merupakan salah satu fluida yang bersifat Non Newtonian yaitu fluida yang mengalami perubahan viskositas akibat gaya yang diberikan, seperti gaya gesek, bahan yang ditambahkan, peningkatan suhu maupun tekanan. Dalam penelitian ini, viskositas madu berubah karena komposisi bahan dan pengemulsi yang ditambahkan. Pada Gambar 1, diketahui bahwa tiap perlakuan memiliki nilai viskositas yang bervariasi. Kelompok perlakuan dengan nilai viskositas tertinggi terdapat pada kelompok T1Tw1 dengan nilai 26 Pas, dan terkecil pada kelompok T1Tw1 22,5 Pas. Namun perbedaan antar kelompok tidak berbeda secara signifikan ( $p$ value $>0,05)$

Pada Gambar 2, terdapat hubungan yang negatif antara peningkatan konsentrasi tokoferol dan viskositas. Nilai $\mathrm{R}^{2}$ 0,657 dan $p$ value $>0,05$ menunjukkan hubungan yang dihasilkan tidak bermakna. Meskipun tidak bermakna, namun penelitian ini sejalan dengan penelitian yang dilakukan Goncalves et al pada tahun tahun 2011, penggunaan tokoferol $2 \%$ b/b dapat menurunkan viskositas dari emulsi yang dihasilkan. Mekanisme ini terjadi dikarenakan tokoferol berperan dalam menjaga interaksi atau tolakan elektrostastik antar molekul (Zhanli et al., 2018).

Sebaliknya, peningkatan konsentrasi Tween 80 berhubungan positif terhadap peningkatan viskositas secara bermakna dengan nilai $\mathrm{R}^{2} 0,995$ dan $p$ value $<$ 0,05 . Pemberian tween 80 berhubungan dengan peningkatan viskositas emulsi.

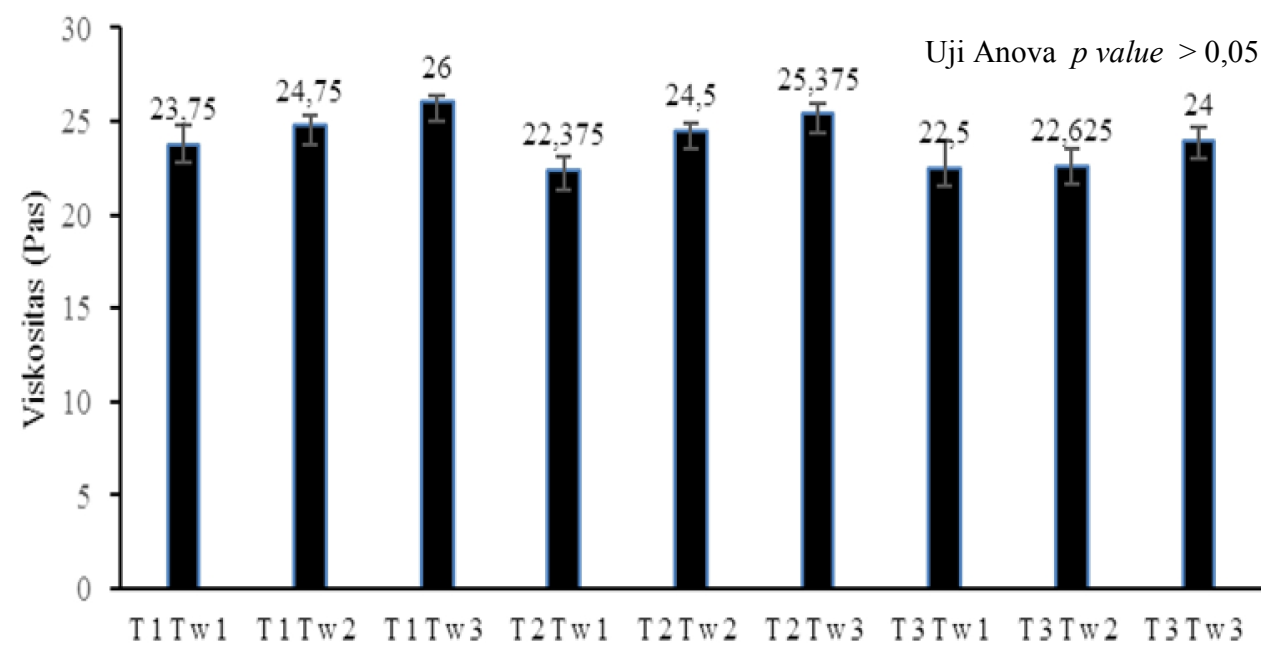

Gambar 1. Nilai viskositas kelompok perlakuan 

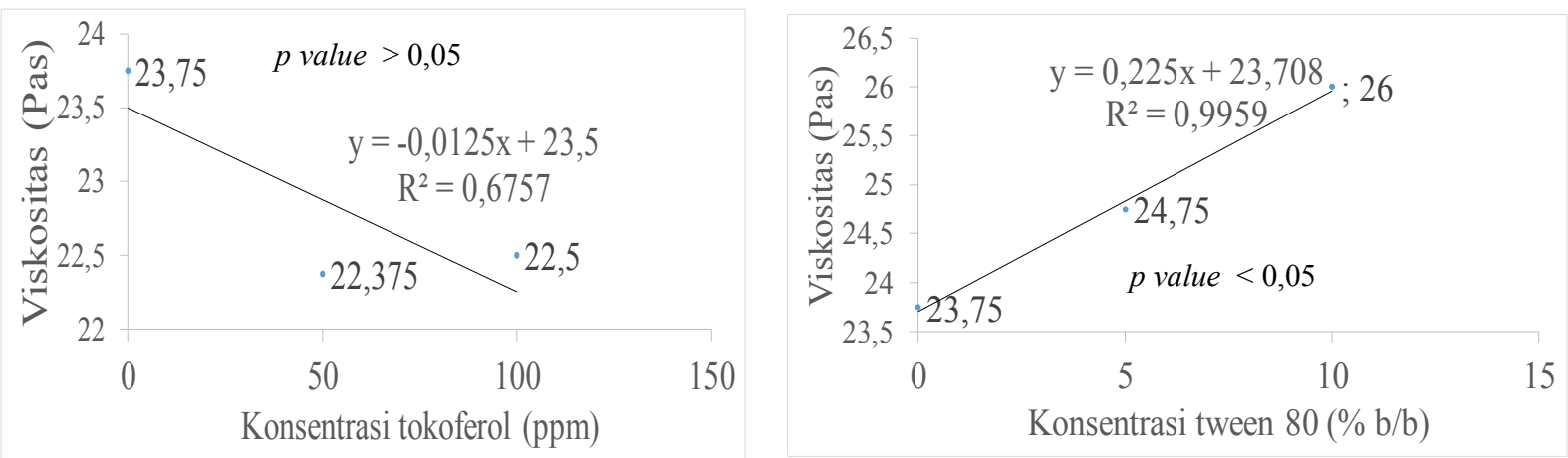

Gambar 2. Hubungan tokoferol dan Tween 80 terhadap viskositas

Penelitian ini sejalan dengan penelitian yang dilakukan oleh Gomes et al pada tahun 2019, peningkatan konsentrasi Tween 80 dari $0-1 \%$ dapat meningkatkan viskositas emulsi o/w. Hal ini berhubungan dengan semakin rigidnya medium pendispersi akan mengakibatkan peningkatan viskositas pada sistem mikroemulsi. Selain itu, pengemulsi juga meminimalkan pergerakan dari droplet ke dalam medium pendispersi, sehingga dapat berdampak pada nilai viskositasnya (Saeedi et al., 2015).

Pada uji lanjut univariat kombinasi keduanya tidak memberikan pengaruh yang signifikan terhadap viskositas madu herbal ( $p$ value $>0,05)$. Hasil ini membuktikan bahwa penambahan tokoferol dan tween 80 tidak memberikan pengaruh yang signifikan pada tiap kelompok. Tidak adanya perubahan yang bermakna menjadikan kedua faktor tersebut dapat menjaga mutu madu herbal dari sisi viskositas atau kekentalan.

\subsection{Distribusi ukuran partikel emulsi}

Ukuran partikel emulsi merupakan parameter keberhasilan dari pembuatan emulsi. Ukuran partikel dilihat dari nilai rerata, serta sebaran dari ukuran partikel yang dapat diamati melalui pesebaran nilai D10, D50 dan D90. Nilai tersebut dihasilkan dengan melihat nilai dari $10 \%, 50 \%$ dan $90 \%$ diameter partikel dari keseluruhan partikel emulsi yang dihasilkan. Pada Gambar 3 menunjukkan kelompok T3TW3 (Konsentrasi tokoferol 0,01\% dan tween 80 0,002\%) memiliki ukuran partikel terkecil dibandingkan perlakuan lain, dengan ukuran partikel rata-rata $117,10 \pm 1,56 \mathrm{~nm}$. Di sisi lain, ukuran partikel terbesar adalah pada perlakuan T1TW1 (konsentrasi tokoferol $0 \%$ dan tween $800 \%$ ) dengan ukuran partikel emulsi 1004,7 $\pm 5,80 \mathrm{~nm}$. Dilihat dari ukurannya kelompok T3Tw3 termasuk dalam kategori mikroemulsi karena ukurannya kurang dari $200 \mathrm{~nm}$ (Komaiko dan McClements 2015). Berdasarkan uji beda, setiap kelompok memiliki ukuran partikel yang berbeda secara siginifikan ( $p$ value $<0,05)$.

Pemberian tokoferol dan Tween 80 memberikan pengaruh terhadap penurunan ukuran partikel emulsi. Berdasarkan Gambar 4, dilihat dari nilai $\mathrm{R}^{2}$ dan $p$ value diketahui peningkatan konsentrasi tokoferol dan tween 80 berkorelasi signifikan terhadap penurunan ukuran partikel emulsi. Hasil ini sejalan dengan penelitian Saberi pada tahun 2013 bahwa penggunaan tokoferol pada konsentrasi $0-8 \%$ dan tween 80 dengan konsentrasi $0,002 \%$ dapat menurunkan ukuran partikel emulsi.

Tokoferol mempunyai sifat yang sangat larut dalam minyak. Pada saat tokoferol dilarutkan ke minyak, dengan disertai pengadukan. Kondisi ini mengakibatkan tegangan permukaan minyak menurun, serta terjadi peningkatan interaksi antara partikel. Tokoferol kemudian mengikat partikel minyak dan menjaga interaksi antara molekul yang terbentuk (Saberi et al., 2013).

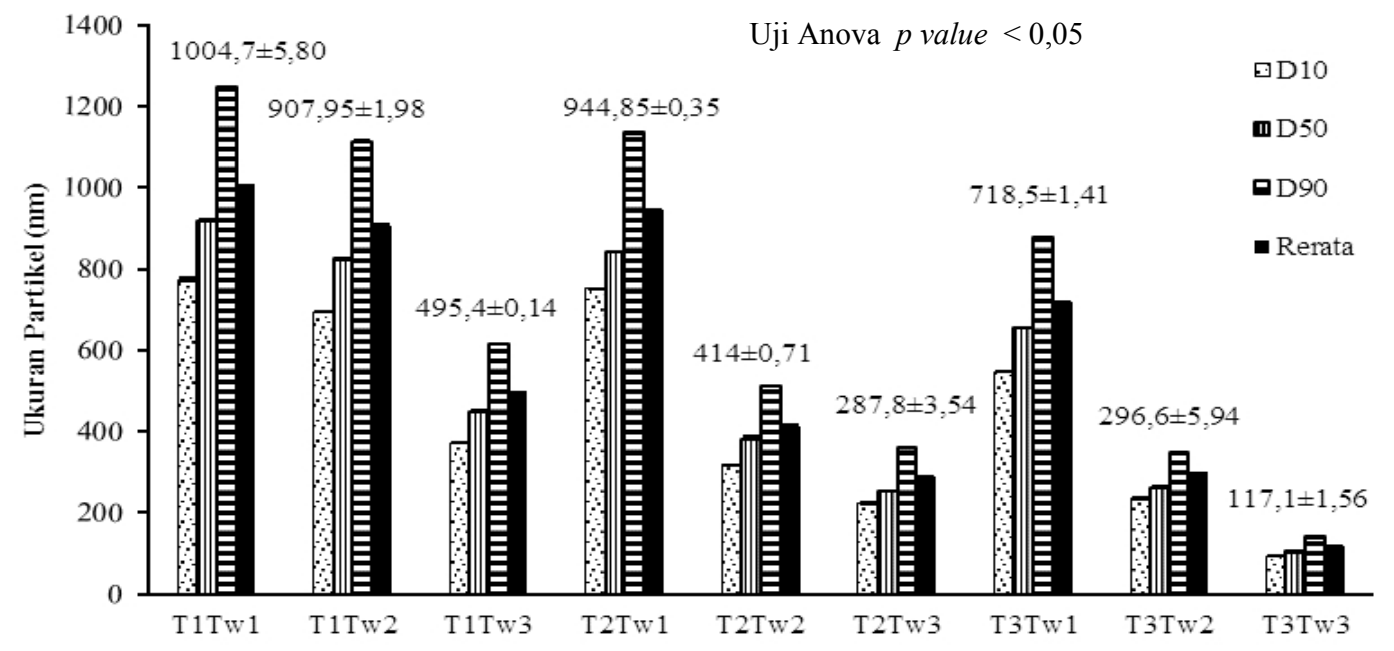

Gambar 3. Distribusi ukuran partikel emulsi 

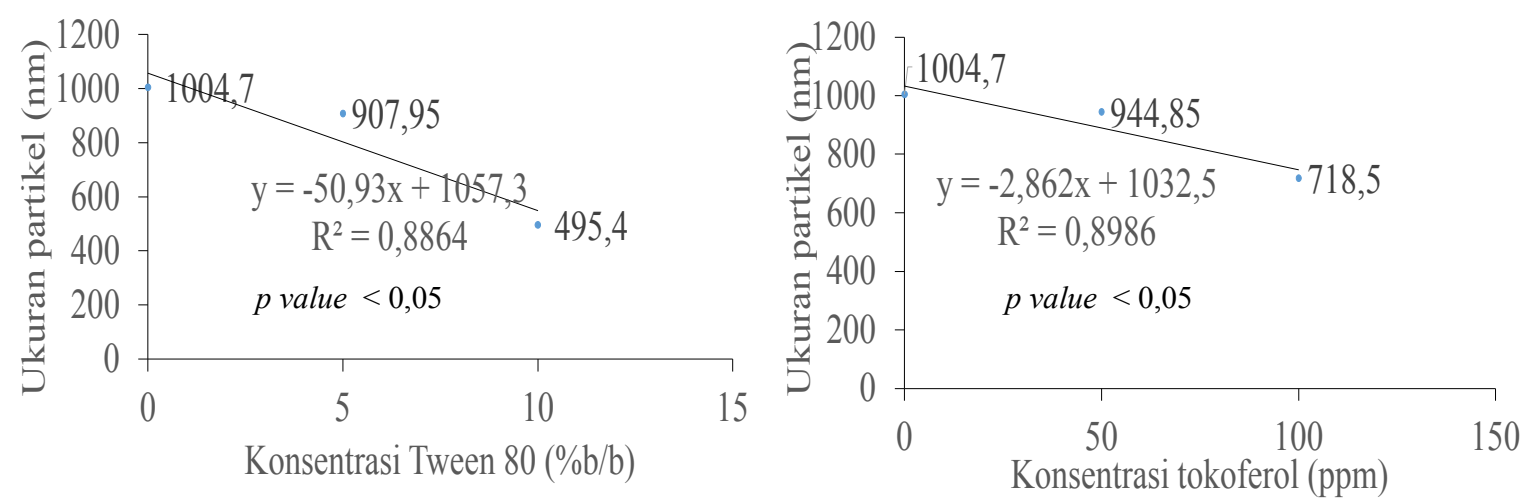

Gambar 4. Hubungan konsentrasi tokoferol dan Tween 80 terhadap ukuran partikel

Pengadukan dan peningkatan suhu dapat memicu turbulensi atau peningkatan pergerakan partikel dan penurunan tegangan permukaan minyak. Dengan kondisi tersebut memudahkan Tween 80 yang mempunyai nilai HLB 15 (lebih bersifat lipofilik) untuk berdifusi ke dalam partikel minyak, selanjutnya mengakibatkan emulsi pecah atau mengalami fase inversi. Partikel minyak yang sangat kecil dapat terbentuk melalui fase inversi tersebut. Mekanisme ini merupakan mekanisme emulsifikasi secara spontan (Riehm et al., 2017; Saberi et al., 2013)

\subsection{Stabilitas emulsi madu herbal terhadap separasi}

Separasi adalah suatu kondisi yang diakibatkan karena tidak terbentuknya emulsi yang optimal, ini mengakibatkan terjadinya pemisahan dua bahan yang memiliki densitas yang berbeda. Pada Gambar 5 diketahui bahwa semua kelompok perlakuan mengalami pemisahan setelah dilakukan penyimpanan pada suhu $40^{\circ} \mathrm{C}$ selama 1 minggu, kecuali pada perlakuan T3Tw3.
Variasi Tween 80 dinilai dapat menjaga kestabilan emulsi madu herbal terhadap pemisahan. Semakin besar Tween 80 yang ditambahkan, semakin stabil pula emulsi yang dihasilkan (Rahmah Elfiyani, Anisa Amalia, 2017). Hal ini berkaitan dengan semakin banyak pengemulsi tween 80 yang ditambahkan memicu emulsi spontan menjadi lebih baik.

Metode emulsifikasi secara spontan dapat membantu pembentukan ukuran partikel emulsi yang kecil dan stabil terhadap pemisahan (Mcclements dan Gumus 2016). Penelitian ini sejalan dengan penelitian lain yang menjelaskan pengaruh pengemulsi terhadap peningkatan stabilitas emulsi o/w. Penelitian yang dilakukan oleh Komaiko pada tahun 2015 menunjukkan bahwa penambahan pengemulsi Tween 80 sebanyak 2\% memberi pengaruh yang baik dalam menjaga stabilitas emulsi yang dihasilkan. Penelitian lain menunjukkan bahwa pembuatan mikroemulsi secara spontan dapat dilakukan dengan menambahkan Tween $80 \quad 2-5 \%$ mampu meningkatkan stabilitas emulsi terhadap pemisahan (Ariviani et al., 2015).

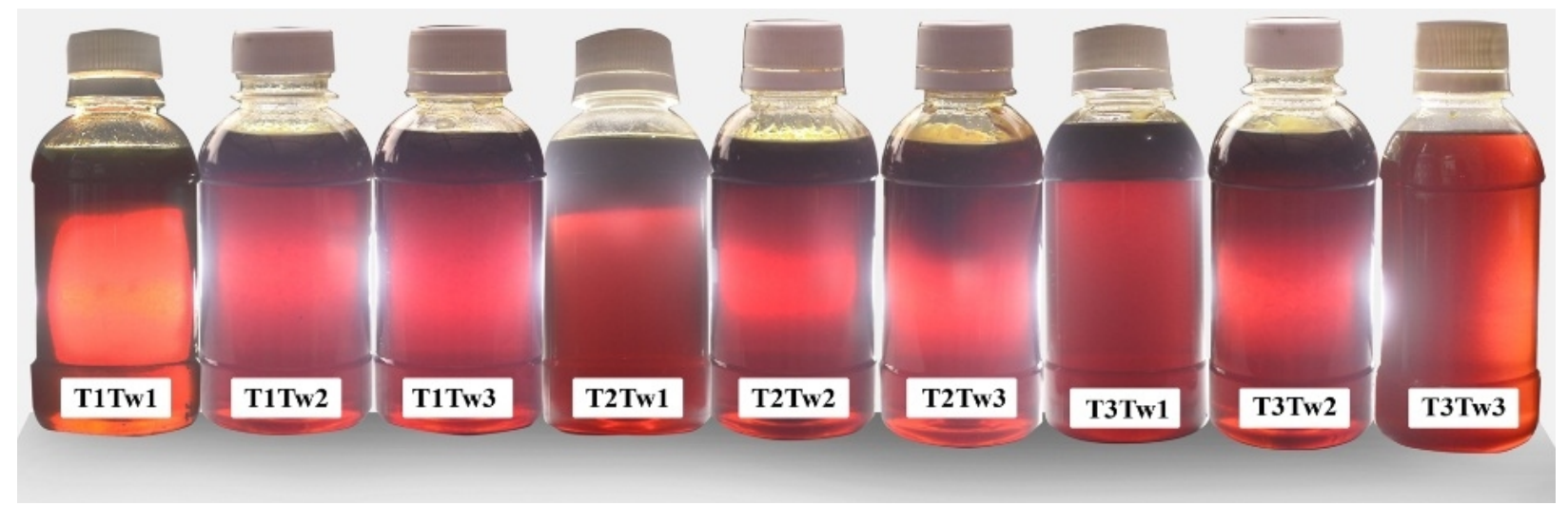

Gambar 5. Visualisasi madu herbal setelah penyimpanan kelompok T1-3 (Tokoferol 0; 0,005; 0,01 \%), Tw1-3

(Tween 80 0; 0,001;0,002\%)

Pada penelitian ini, madu dengan emulsifier $10 \%$ memiliki kestabilan terhadap pemisahan yang lebih baik dibandingkan yang lain. Namun, dilihat dari penampakannya perlakuan T3TW3 selama penyimpanan mengalami perubahan transparansi dan kepekatan. Mikroemulsi yang seharusnya memiliki penampakan yang transparan dan tidak keruh berubah menjadi kurang transparan dan agak keruh (Mcclements and Gumus,
2016). Perubahan warna pada emulsi berkaitan dengan sifat Tween 80 yang sensitif terhadap temperatur sehingga mempengaruhi kestabilannya secara sistem termodinamika. Peningkatan suhu mengakibatkan perubahan sifat Tween 80 menjadi lebih bersifat lipofilik. Kondisi ini disebabkan karena gugus polioksietilen yang berfungsi sebagai gugus polar pada bagian kepala mengalami dehidrasi dengan 
meningkatnya suhu. Peningkatan suhu mengakibatkan tegangan permukaan minyak dan air meningkat. Hal ini berhubungan dengan perubahan penampakan emulsi menjadi keruh dan kurang transparan (Fitriani et al., 2016).

Meskipun demikian, emulsifier Tween 80 mempunyai peran melindungi senyawa aktif di dalam emulsi dan mencegah difusi minyak ke dalam air terjadi kembali (Anarjan et al., 2013). Di sisi lain, tokoferol juga berperan dalam mencegah terbentuknya alkil radikal yang dapat menyebabkan penggumpalan maupun penggabungan antara partikel minyak yang telah terbentuk sebelumnya (Kim et al., 2018). Variasi tokoferol berdampak pada kestabilan emulsi terhadap pemisahan emulsi. Gambar 5. menunjukkan bahwa perlakuan T3TW3 memiliki kestabilan emulsi terbaik.

\subsection{Stabilitas madu herbal dengan menggunakan ASLT}

Pengujian ASLT didasarkan pada perubahan nilai TBA pada madu herbal dengan mempercepat laju reaksi menggunakan suhu 35, 40 dan $45^{\circ} \mathrm{C}$. Berikut perubahan nilai TBA yang terjadi pada madu herbal dengan penambahan antioksidan dan emulsifier (A), dan madu tanpa penambahan antioksidan dan emulsifier (B) selama penyimpanan. Pada Gambar 6, diketahui terdapat peningkatan nilai TBA yang mengindikasikan terjadinya kerusakan kimia, khususnya kerusakan pada minyak yang terkandung di dalam madu herbal. Peningkatan suhu mengakibatkan peningkatan kecepatan pada kerusakan kimia (Haouet et al., 2018).
Kurva slope kelompok A ordo 0

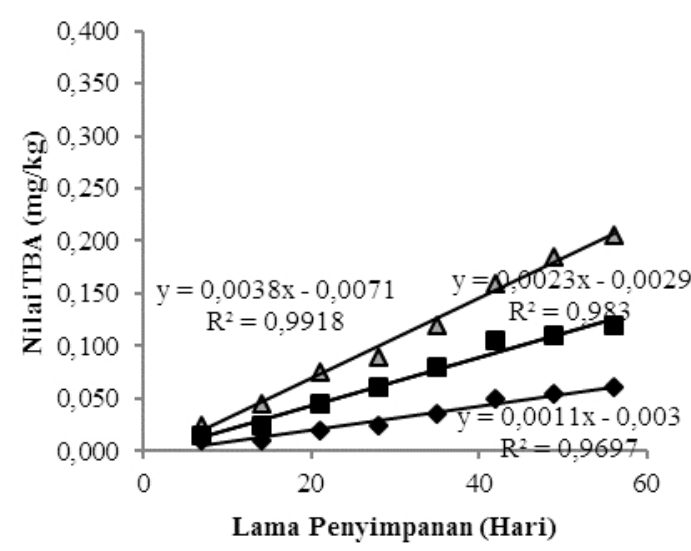

Kurva slope kelompok A ordo 1

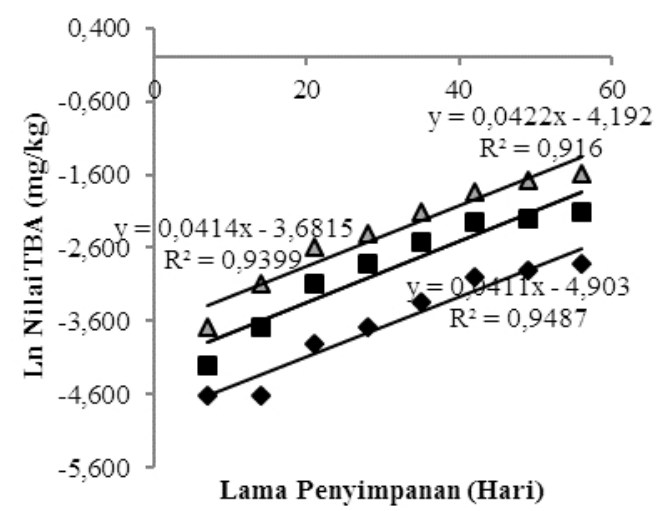

Kurva slope kelompok B ordo 0

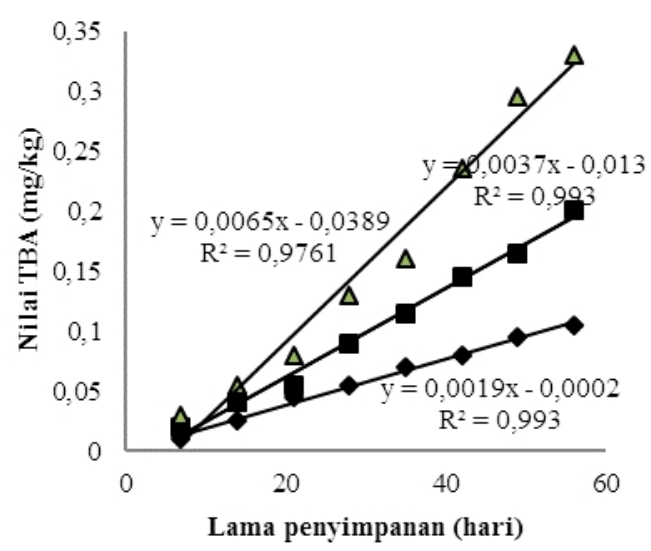

Kurva slope kelompok B ordo 1

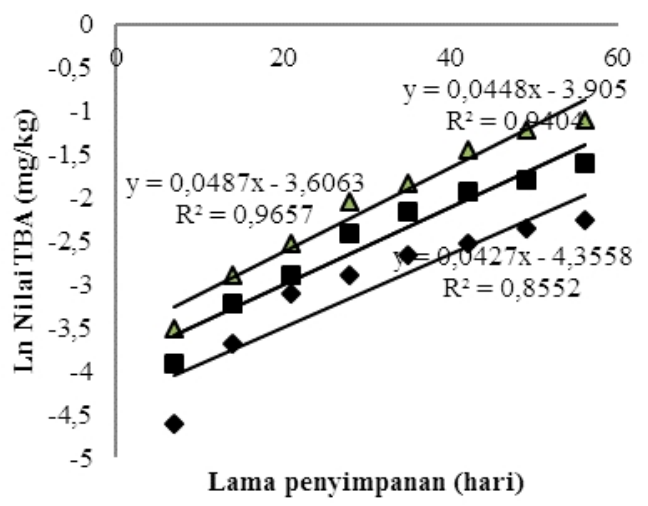

Gambar 6. Grafik peningkatan nilai TBA kelompok A dan kelompok B pada suhu $35^{\circ} \mathrm{C}(\diamond)$, suhu $40^{\circ} \mathrm{C}(\boldsymbol{\square})$ dan suhu $45^{\circ} \mathrm{C}(\boldsymbol{\Delta})$ pada ordo 0 dan 1 .

Berdasarkan Tabel 2, semua kelompok memiliki $\mathrm{R}^{2}$ $>0,7$, dan nilai $\mathrm{k}$ meningkat seiring dengan peningkatan suhu penyimpanan. Dimana nilai $\mathrm{R}^{2}$ pada ordo 0 lebih besar dibandingkan ordo 1 , nilai tersebut dijadikan acuan dalam pemilihan ordo yang digunakan. Selanjutnya nilai $\mathrm{k}$ pada kelompok $\mathrm{B}$ lebih tinggi dibandingkan dengan kelompok A. Hal ini menunjukkan bahwa laju peningkatan nilai TBA pada kelompok A lebih tinggi dibandingkan kelompok A. Perbedaan ini disebabkan karena terjadinya reaksi oksidasi yang tinggi pada kelompok B. Setelah mendapatkan nilai $\mathrm{k}$ dan $\mathrm{R}^{2}$, maka dilakukan pembuatan persamaan Arrhenius dan menghitung prediksi umur simpan yang dapat dilihat pada Tabel 2 dan Tabel 3.

Tabel 3 menyajikan persamaan Arrhenius, energi aktifasi dan nilai koefisian determinasi. Energi aktivasi adalah energi minimum yang dibutuhkan untuk mengaktifkan reaksi. Suhu mempunyai pengaruh terhadap energi aktivasi. Semakin tinggi suhu yang digunakan, semakin cepat reaksi dan kerusakan yang 
terjadi. Nilai energi diklasifikasikan menjadi tiga kategori yaitu kecil (2-15 kkal/mol), sedang (15-30 $\mathrm{kkal} / \mathrm{mol}$ ), dan tinggi (50-100 kkal/mol) (Arpah M, 2007).

Kelompok A dan Kelompok B masing masing memiliki energi aktivasi $24,22 \mathrm{kkal} / \mathrm{mol}$ dan 24,02 $\mathrm{kkal} / \mathrm{mol}$ yang termasuk dalam kategori sedang. Besarnya energi aktivasi pada kelompok B dibandingkan kelompok A menunjukkan bahwa laju reaksi kelompok B lebih cepat dibandingkan kelompok A. Selanjutnya, setelah diketahui energi aktivasi dari masing-masing perlakuan, kemudian dilakukan perhitungan pendugaan umur simpan.

Tabel 2

Nilai koefisien determinasi dan laju kinetika reaksi nilai TBA

\begin{tabular}{llllll}
\hline \multirow{2}{*}{ Ordo } & $\begin{array}{l}\text { Suhu } \\
\end{array}$ & \multicolumn{2}{c}{ Kelompok A } & \multicolumn{2}{c}{ Kelompok B } \\
\cline { 2 - 6 } & & $\mathrm{R}^{2} \mathrm{C}$ & $\mathrm{k}$ & $\mathrm{R}^{2}$ & $\mathrm{~K}$ \\
\hline \multirow{3}{*}{0} & 35 & 0,969 & 0,001 & 0,991 & 0,001 \\
\cline { 2 - 6 } & 40 & 0,983 & 0,002 & 0,991 & 0,003 \\
\cline { 2 - 6 } & 45 & 0,991 & 0,003 & 0,976 & 0,006 \\
\hline \multirow{3}{*}{1} & 35 & 0,948 & 0,041 & 0,852 & 0,042 \\
\hline & 40 & 0,916 & 0,041 & 0,940 & 0,044 \\
\hline
\end{tabular}

Tabel 3

Persamaan Arrhenius, energi aktivasi dan koefisien determinasi

\begin{tabular}{ll}
\hline Kelompok & Persamaan Arrhenius \\
\hline $\mathrm{A}$ & $\ln \mathrm{k}=-12149(1 / \mathrm{T})+32,65$ \\
& $\mathrm{Ea}=24,22 \mathrm{kkal} / \mathrm{mol}$ \\
& $\mathrm{R}^{2}=0,996$ \\
\hline $\mathrm{B}$ & $\ln \mathrm{k}=-12051(1 / \mathrm{T})+32,87$ \\
& $\mathrm{Ea}=24,02 \mathrm{kkal} / \mathrm{mol}$ \\
& $\mathrm{R}^{2}=0,988$ \\
\hline
\end{tabular}

Tabel 4

Pendugaan umur simpan madu herbal pada suhu $35^{\circ} \mathrm{C}$

\begin{tabular}{llll}
\hline Kelompok & $\begin{array}{l}\text { Nilai kritis } \\
(\mathrm{a}-\mathrm{a} 0)\end{array}$ & $\mathrm{k}$ & $\begin{array}{l}\text { Umur simpan } \\
\text { (hari) }\end{array}$ \\
\hline $\mathrm{A}$ & 0,27 & 0,0011 & 241 \\
\hline $\mathrm{B}$ & 0,27 & 0,0019 & 140 \\
\hline
\end{tabular}

Berdasarkan Tabel 6, kelompok A memiliki umur simpan 241 hari dan kelompok B memiliki umur simpan 140 hari pada suhu $35^{\circ} \mathrm{C}$. Pada kelompok A yaitu kelompok madu herbal yang ditambahkan antioksidan tokoferol $10 \%$ dan emulsifier Tween 80 memiliki umur simpan yang lebih panjang dibandingkan kelompok B. Hal ini membuktikan bahwa antioksidan dan emulsifier berpengaruh terhadap stabilitas madu herbal selama penyimpanan.

Madu herbal yang ditambahkan antioksidan dan emulsifier dianggap dapat menahan laju reaksi oksidasi yang lebih baik dibandingkan kelompok tanpa antioksidan dan emulsifier. Dalam emulsi o/w, tokoferol bekerja di area permukaan minyak. Antioksidan ini bekerja dengan melindungi minyak dari fase air yang merupakan cara yang baik untuk mencegah terjadinya oksidasi dan bersatunya alkil radikal yang dapat berubah menjadi peroksil radikal maupun TBA (Frankel, 1996).

Tokoferol berperan menghambat oksidasi radikal bebas tersebut melalui bereaksi dengan peroksil radikal untuk menghentikan rantai propagasi. Tokoferol beraksi melalui berkompetisi dengan asam lemak (RH) untuk membawa peroksil radikal, sehingga dapat merusak rantai oksidasi. Tokoferol radikal dapat membentuk produk non radikal termasuk dimer, peroksida yang stabil atau turunan tak jenuh melalui jalur regenerasi (Frankel, 1996).

Madu murni memiliki kandungan vitamin, mineral, dan antioksidan di dalamnya. Kandungan vitamin $\mathrm{C}$ dalam madu dinilai dapat menjadi antioksidan yang baik untuk melawan radikal bebas. Selain itu, flavonoid dan senyawa fenolik juga memberikan pengaruh yang baik dalam perlindungan terhadap reaksi oksidasi (Arawwawala and Hewageegana, 2017). Namun, kandungan bahan aktif tersebut belum cukup untuk menahan laju oksidasi dari madu herbal yang ditambahkan minyak jintan hitam dan minyak zaitun, sehingga dibutuhkan antioksidan tambahan untuk menghambat laju oksidasi yang terjadi.

\section{Kesimpulan}

Madu herbal dengan kekuatan emulsi yang optimal dihasilkan dengan penambahan antioksidan pada konsentrasi $0,01 \%$ tokoferol dan $0,002 \%$ Tween 80 yang ditunjukkan dengan kemampuannya dalam menahan laju pemisahan emulsi selama penyimpanan. Penambahan antioksidan tokoferol dan pengemulsi Tween 80 dapat membantu pembentukan ukuran partikel emulsi yang lebih kecil, namun tidak merubah viskositas dalam madu herbal, sehingga dinilai kedua bahan tersebut dapat memperbaiki emulsi yang dihasilkan.

Stabilitas madu herbal selama penyimpanan mengalami peningkatan dari 140 hari menjadi 241 hari pada suhu $35^{\circ} \mathrm{C}$. Hasil ini menunjukkan bahwa penambahan antioksidan dan pengemulsi dapat meningkatkan stabilitas dan umur simpan produk.

\section{Saran}

Pada penelitian selanjutnya perlu diamati stabilitas madu herbal selama penyimpanan menggunakan parameter kritis lainnya dengan menggunakan jenis emulsifier dan antioksidan lainnya.

\section{Daftar pustaka}

Aladedunye, A.F., Przybylski, R., 2009. Degradation and nutritional quality changes of oil during frying. JAOCS, J. Am. Oil Chem. Soc. 86, 149-156. https://doi.org/10.1007/s11746-008-1328-5

Alturkistani, H., Abuzinadah, O., Kelany, A., El-Aziz, G., Alrafiah, A., 2019. The combined effect of honey and olive oil against methotrexate mediated hepatotoxicity in rats: A biochemical, histological and immunohistological study. Histol. Histopathol. 34, 1313-1327. https://doi.org/10.14670/HH-18-126

Anarjan, N., Nehdi, I.A., Tan, C.P., 2013. Influence of 
astaxanthin, emulsifier and organic phase concentration on physicochemical properties of astaxanthin nanodispersions. Chem. Cent. J. 7, 1. https://doi.org/10.1186/1752-153X-7-127

Arawwawala, M., Hewageegana, S., 2017. Health benefits and traditional uses of honey: A review. J. Apitherapy 2 2. https://doi.org/10.5455/ja. 20170208043727

Ariviani, S., Raharjo, S., Anggrahini, S., Naruki, S., 2015. Formulasi dan stabilitas mikroemulsi O/W dengan metode emulsifikasi spontan menggunakan VCO dan minyak sawit sebagai fase minyak: pengaruh rasio surfaktan-minyak. J. Agritech 35, 27. https://doi.org/10.22146/agritech.9416

Arpah, M., 2007. Penetapan kadaluwarsa pangan. Departemen Ilmu dan Teknologi Pangan Institut Pertanian Bogor.

Banfalvi, G., 2016. Permeability of biological membranes. https://doi.org/10.1007/978-3-31928098-1

Choe, E., Min, D., 2009. Mechanisms of antioxidants in the oxidation of foods. Compr Rev Food Sci F 8:345358. Compr. Rev. Food Sci. Food Saf. 8, 345-358. https://doi.org/10.1111/j.1541-4337. 2009.00085.x

Dianingsih, N., Hari Purnomo, E., R. Muchtadi, T., 2016. Sifat reologi dan stabilitas fisik minuman emulsi minyak sawit. J. Teknol. dan Ind. Pangan. https://doi.org/10.6066/jtip.2016.27.2.165

Fallico, B., Arena, E., Zappala, M., 2009. Prediction of honey shelf life. J. Food Qual. 32, 352-368. https://doi.org/10.1111/j.1745-4557.2009.00253.x

Fitriani, E.W., Imelda, E., Kornelis, C., Avanti, C., 2016. Karakterisasi dan stabilitas fisik mikroemulsi tipe A/M dengan berbagai fase minyak. Pharm. Sci. Res. 3, 31-44. https://doi.org/10.7454/psr. v3i1.3221

Frankel, E.N., 1996. Antioxidants in lipid foods and their impact on food quality. Food Chem. 57, 51-55. https://doi.org/10.1016/0308-8146(96)00067-2

Haouet, M.N., Tommasino, M., Mercuri, M.L., Benedetti, F., Di Bella, S., Framboas, M., Pelli, S., Altissimi, M.S., 2018. Experimental accelerated shelf life determination of a ready-to-eat processed food. Ital. J. Food Saf. 7, 189-192. https://doi.org/10.4081/ijfs.2018.6919

Hassan, A.K., 2015. Effective surfactants blend concentration determination for $\mathrm{o} / \mathrm{w}$ emulsion stabilization by two nonionic surfactants by simple linear regression. Indian J. Pharm. Sci. 77, 461-469. https://doi.org/10.4103/0250-474X.164773

Hassanien, M., Wahdan, K., 2011. Blending of corn oil with black cumin (Nigella sativa) and coriander (Coriandrumsativum) seed oils: Impact on functionality, stability and radical scavenging activity. Food Chem. 132, 873-879. https://doi.org/10.1016/j.foodchem.2011.11.054

Husain, R., Suparmo, S., Harmayani, E., Hidayat, C., 2018. Komposisi asam lemak, angka peroksida, dan angka TBA fillet ikan kakap (Lutjanus $s p$ ) pada suhu dan lama penyimpanan berbeda. Agritech. https://doi.org/10.22146/agritech.11212

Kim, J., Song, H.Y., Choi, S.J., 2018. Influence of oxidants on the stability of tocopherol in model nanoemulsions: role of interfacial membrane organized by nonionic emulsifiers. J. Chem. 2018. https://doi.org/10.1155/2018/6438787

Komaiko, J., McClements, D.J., 2015. Food-grade nanoemulsion filled hydrogels formed by spontaneous emulsification and gelation: Optical properties, rheology, and stability. Food Hydrocoll. 46, 67-75. https://doi.org/10.1016/ j.foodhyd.2014.12.031

Komaiko, J.S., Mcclements, D.J., 2016. Formation of food-grade nanoemulsions using low-energy preparation methods: a review of available methods. Compr. Rev. Food Sci. Food Saf. 15, 331-352. https://doi.org/10.1111/1541-4337.12189

Mcclements, D., Gumus, C., 2016. Natural emulsifiers - biosurfactants, phospholipids, biopolymers, and colloidal particles: Molecular and physicochemical basis of functional performance. Adv. Colloid Interface Sci. 234. https://doi.org/10.1016/j.cis. 2016.03.002

Murakami, R., Moriyama, H., Noguchi, T., Yamamoto, M., Binks, B.P., 2014. Effects of the density difference between water and oil on stabilization of powdered oil-in-water emulsions. Langmuir 30, 496500. https://doi.org/10.1021/la4042056

Picandet, V., 2017. Particle size distribution, in: RILEM State-of-the-Art Reports. https://doi.org/10.1007/ 978-94-024-1031-0 4

Pristouri, G., Badeka, A., Kontominas, M.G., 2010. Effect of packaging material headspace, oxygen and light transmission, temperature and storage time on quality characteristics of extra virgin olive oil. Food Control 21, 412-418. https://doi.org/10.1016/j. foodcont.2009.06.019

Rahmah Elfiyani, Anisa Amalia, S.Y.P., 2017. Effect of using the combination of tween 80 and ethanol on the forming and physical stability of microemulsion of eucalyptus oil as antibacterial. J. Young Pharm. 9, 107-114. https://doi.org/ 10.5530/jyp.2017

Riehm, D.A., Rokke, D.J., Paul, P.G., Lee, H.S., Vizanko, B.S., McCormick, A. V., 2017. Dispersion of oil into water using lecithin-Tween 80 blends: The role of spontaneous emulsification. J. Colloid Interface Sci. https://doi.org/ 10.1016/j.jcis. 2016.10.010

Saberi, A.H., Fang, Y., McClements, D.J., 2013. Fabrication of vitamin E-enriched nanoemulsions: Factors affecting particle size using spontaneous emulsification. J. Colloid Interface Sci. 391, 95-102. https://doi.org/10.1016/j.jcis.2012.08.069

Saeedi, M., Rafati, M.R., Morteza-Semnani, K., Yazdani Rostam, A., Kelidari, H.R., 2015. Evaluation of effect of tween 80 on characteristics of tadalafil $0.1 \%$ suspension. Pharm. Biomed. Res. 1, 35-43. https://doi.org/10.18869/acadpub.pbr.1.2.35

Shikh Maidin, M., Padlan, M.H., Azuan, S.A.N., Jonit, R., Mohammed, N.H., Abdullah, R., 2018. Supplementation of Nigella sativa oil and honey prolong the survival rate of fresh and post-thawed goat sperms. Trop. Anim. Sci. J. 41, 94-99. https://doi.org/10.5398/tasj.2018.41.2.94

Srivastava, Y., Semwal, A., 2013. A study on monitoring of frying performance and oxidative stability of virgin coconut oil (VCO) during 
continuous/prolonged deep fat frying process using chemical and FTIR spectroscopy. J. Food Sci. Technol. 52. https://doi.org/10.1007/s13197-0131078-8

Vrbiková, L., Schmidt, Š., Kreps, F., Tmáková, L., Čertík, M., Sekretár, S., 2014. Degradation of selected nutrients in sunflower oils during long-term storage. Czech J. Food Sci. 32, 595-600. https://doi.org/10.17221/176/2014-cjfs

Zhanli, L.Z., Wang, X., LingLi, L., Yang Sun, 2018. Effect of $\alpha$-tocopherol antioxidant on rheological and physicochemical properties of chitosan/zein edible films. LWT 118. 